\title{
SÚLYOS-HALMOZOTTAN SÉRÜLT GYERMEKEK RÉSZVÉTELE A CSALÁDI TEVÉKENYSÉGEKBEN
}

\section{Szerzők:}

Pető Ildikó

Debreceni Egyetem, Gyermeknevelési és

Gyógypedagógiai Kar

Első szerző e-mail címe: peto.ildiko@ped.unideb.hu

\section{Lektorok:}

Varga Imre

Szegedi Tudományegyetem

(Magyarország)

Vargáné Nagy Anikó

Debreceni Egyetem

(Magyarország)

Pető Ildikó (2018): Súlyos-halmozottan sérült gyermekek részvétele a családi tevékenységekben. Különleges Bánásmód, IV. évf. 2018/4. szám, 83-98. DOI 10.18458/KB.2018.4.83

\begin{abstract}
Absztrakt
Kevés olyan vizsgálat van, ami a súlyos-halmozottan fogyatékos (súlyosan-halmozottan fogyatékos) gyermekeknek az otthoni, családi környezetben való jelenlétét vizsgálta. A jelen irás célja, hogy végiggondolja, összefoglalja a gyermekek részvételét a családi tevékenységekben, hogy mennyire tudnak valóban családtagok lenni.

A „részvételt" részben úgy definiálhatjuk, hogy a személy fizikailag ott van, jelen van valahol, valamilyen tevékenység során, részben pedig, mint elkötelezödést, aktív részvételt a tevékenységben. De egy tevékenységben, eseményben való részvétel csak akkor lehetséges, ha a tevékenység bekövetkezik és fel is ajánlják a gyermekeknek vagy a felnötteknek. A súlyos értelmi fogyatékos vagy súlyosan-halmozottan sérült gyermekek és felnöttek ebben az értelemben (is) nagymértékben másoktól függenek.

A családi életben való aktiv részvételt befolyásolhatják, akadályozhatják vagy elösegíthetik például a gyermek jellemzöi, az adott családi tevékenységek gyakorisága, a családi jövedelem, az anya és apa iskolai végzettsége, a szokások, a megvalósitást elösegitö stratégiák és esetleg a személyi segitó.
\end{abstract}

Kulcsszavak: gyógypedagógia, súlyos-halmozottan fogyatékosok

Diszciplina: gyógypedagógia

\begin{abstract}
There are only few studies to investigate the presence of children with profound intellectual and multiple disabilities in their home and family environment. The aim of this paper is to consider and to summarize the participation of children in family activities as to what extent they can actually be family members.

"Participation" can be defined, on the one hand, as the person's physical presence at a place or during some activity, on the other hand, as a commitment, an active participation in the activity. But participation in an activity or event is only possible if the activity occurs and
\end{abstract}


is also offered to children or adults. In this sense, children and adults with profound intellectual and multiple disabilities rely heavily on others.

Active participation in family life may be affected, hindered or promoted by several factors, for example, the characteristics of the child, the frequency of family activities, the family income, the mother's and father's educational level, the habits, the strategies of implementation or eventually the personal assistant.

Keywords: special education, profound intellectual and multiple disabilities

Disciplines: special education

A súlyos-halmozott fogyatékosság meghatározása összetett feladat. Márkus (2003) számos aspektusát felsorolja annak, hogy egy fogalom értelmezése honnan közelíthető meg, orvosi, pszichológiai, jogi, pedagógiai, szociológiai, perszonális és még számos oldalról vizsgálhatunk meg egy definíciót. Hazánkban a súlyosan-halmozottan fogyatékos/sérült személyek kategóriájába a gyógypedagógiai gyakorlat alapján azokat a személyeket értjük „... akik legalább két területen minősülnek fogyatékosnak és ezek közül legalább az egyik területen a legsúlyosabb minősítést kapják.” (Márkus, 2003, 178.o.).

A pedagógiai munkánkat meghatározó rendeletek közül az egyik így fogalmaz: „A súlyos és halmozott fogyatékosság az egész élet során fennálló állapot, amelyre jellemző, hogy a testi struktúrák károsodása következtében a speciálisan humán funkciók - mint a kommunikáció, a beszéd, a mozgás, az értelem és az érzékelés-észlelés - minimálisan két területén súlyos vagy legsúlyosabb mértékü zavar mutatható ki. Ennek következtében az érintett személy pszichofizikai teljesítményei extrém mértékben eltérnek az átlagtól, így tevékenységeiben erősen akadályozottá válik, és társadalmi részvételében jelentősen korlátozott lehet. A súlyos és halmozott fogyatékosság hátterében rendszerint a korai életszakaszban bekövetkező, a központi idegrendszert érintő komplex károsodás áll. A fogyatékosságok a legkülönfélébb kombinációkban és súlyossági fokozatokban, esetleg eltérő időben jelenhetnek meg." (32/2012. (X.8.) EMMI rendelet a Sajátos nevelési igényü gyermekek óvodai nevelésének iránylevei és a Sajátos nevelési igényü tanulók iskolai oktatásának irányelve kiadásáról. 3. melléklet, 190.o.).

Közös jellemzőjük az is, hogy a súlyos-halmozottan fogyatékos gyermekek különböző szempontok szerint (pl. maga a fogyatékosságuk, annak okai, funkcióképességük, viselkedésük, éberségi szintjük) erősen heterogén csoportot alkotnak, de közös jellemzőjük, hogy egyformán nagymértékben függenek másoktól. (Nakken és Vlaskamp 2002, 2007).

A súlyos-halmozottan fogyatékos gyermekek már születésüktől más utat járnak be, mint a tipikusan fejlődő vagy az enyhébb fokban fogyatékos társaik, kortársaikkal nincs, vagy alig van kapcsolatuk és találkozási lehetőségeik. Hazánkban a súlyos-halmozottan fogyatékos gyermekek gyermekközösségben jellemzően csak speciális fejlesztő csoportokban vannak, aminek oka nem csak az akadályozott kommunikációjuk. Igaz, hogy (elsősorban a verbális) kommunikációjuk nehezített vagy éppen (sok esetben) teljesen hiányzik is, de az elégtelen kommunikáció következményeként a környezettel való kontaktusfelvétel is nehezített, ami aztán magával hozza az izolációt.

Az alapjogok biztosának, Székely Lászlónak a jelentése (2017. 09.04.) egy 2015-ös kutatás adataiból kiemeli, hogy a speciális, a súlyos-halmozottan fogyatékos tanulók számára kialakított oktatási keretrendszerben (fejlesztő nevelés-oktatásban) részt vevő tanulók 67 százaléka iskolán kívül teljesíti tankötelezettségét, tehát nem jár iskolába, nem jár 
közösségbe. A törvény értelmezö rendelkezése hiányos a súlyosan és halmozottan fogyatékos tanulók esetében. Eleve ismeretlen az érintettek pontos száma, ám ma Magyarországon körülbelül 3500-4000 súlyosan-halmozottan fogyatékos gyermekek létezésével, évente pedig nagyjából 200 súlyosan, halmozottan fogyatékos gyermek születésével kell számolnunk. (Alapvető Jogok Biztosának Hivatala, 2017).

\section{A súlyosan-halmozottan fogyatékos személyek}

A különböző területek optimális fejlődése elengedhetetlen a bio-psziho-szociális egység kiegyensúlyozott müködéséhez. Fröhlich modellje (1. ábra) (Márkus 2009. 50.old.) jól példázza, hogy a különböző területek egymással szorosan összefüggenek, egymásra hatnak a fejlődésük során. A fejlesztést tekintve ez azt is jelenti, hogy egy-egy területet nem lehet és nem is érdemes izoláltan fejleszteni. A fejlesztés az egész személy (iség)re ható pedagógiai folyamat, melyet a tervezés során figyelembe kell venni. Középpontjában a kommunikáció áll, mely jól illeszkedik ahhoz a szemlélethez, mely a kommunikációt a jéghegy csúcsaként írja le (Fröhlich 1996). A kommunikáció erősen épít más területek fejlődésére, de a kommunikáció maga is visszahat ezekre a területekre. Bármely terület érintetté válik a fejlődés során, az kihat a többi terület fejlődésére, ez igaz természetesen a kommunikációra is.

1. ábra. Komplex fejlödési modell Fröchlich nyomán (forrás: Márkus, 2009, 50.old)

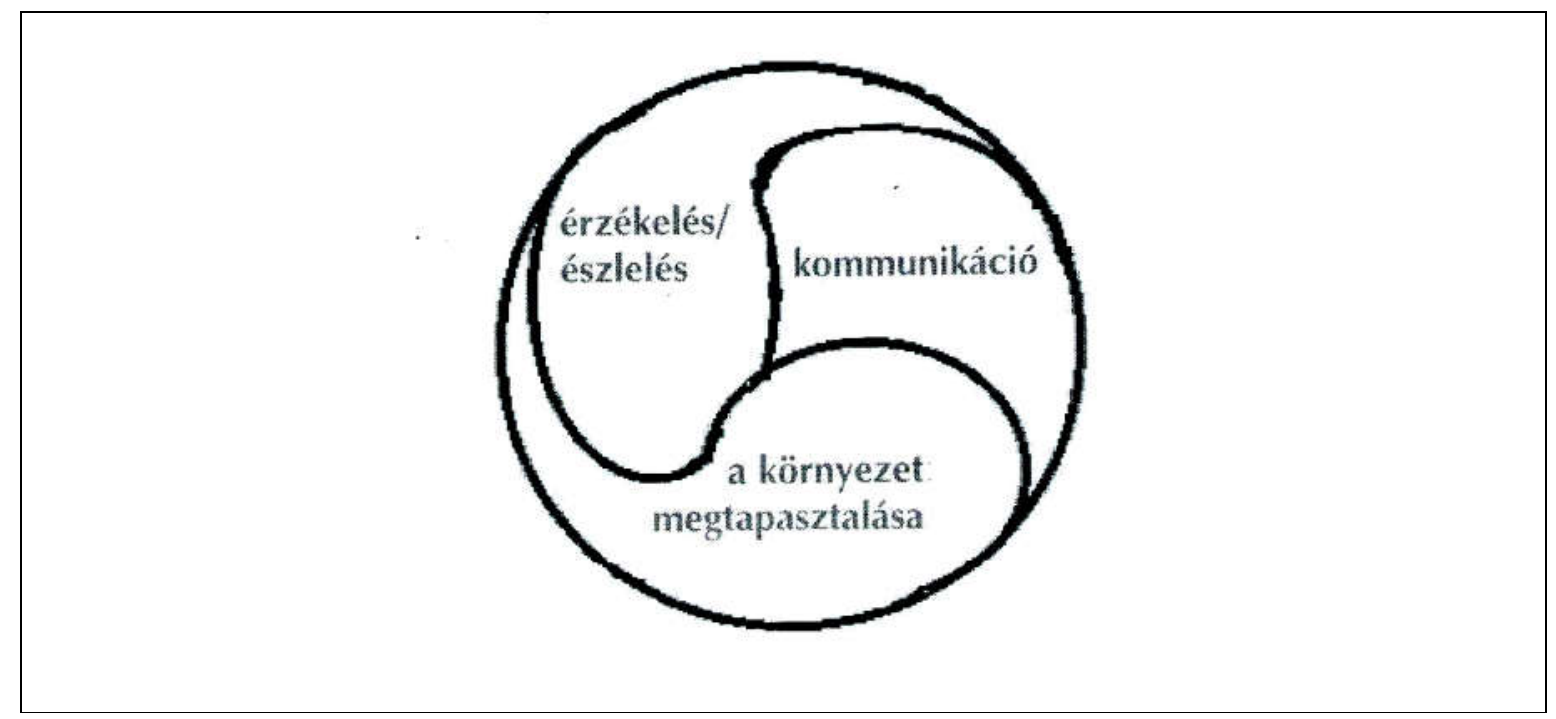

Bronfenbrenner bio-ökológiai rendszerelméleti modellje szerint (2. ábra) a fejlődés az egyén és a közvetlen környezetének komplex, kölcsönös interakcióinak folyamataiban megy végbe, ami különösen a korai időszakban fontos. Ezeknek az interakcióknak, amelyeket Bronfenbrenner proximális folyamatoknak nevezett, rendszeresnek kell lenniük ahhoz, hogy hatékonyakká váljanak. A proximális folyamatok leginkább a szülő-gyerek és a gyerekgyerek kapcsolatban találhatóak meg, de esetenként olyan személy is belekerül, aki nem tartozik szorosan a családhoz. A proximális folyamatok, ami az egyén életében életkorától, a környezettől függően változik, folyamatosan alakul, enyhíthetik vagy éppen ki is védhetik a kedvezőtlen környezeti hatásokat. A Bronfenbrenner-modell összegzi azokat a külső társas társadalmi hatásokat, amelyek hatást gyakorolnak az egyén szocializációjára, mely 
hatásoknak négy különböző szintje van: mikrorendszer, mezorendszer, exorendszer, makrorendszer (Danis. I. és Kalmár, M. (2011).

Egy sérült gyermek általában teljes életmódváltást követel meg az egész családtól. Az édesanyáknak sokszor véglegesen fel kell adniuk a munkájukat, hiszen a gyermekek folyamatos felügyeletet, ellátást igényelnek, így a családok fenntartásának a terhe döntően az édesapákra hárul. A család többi tagjának - nagyszülőknek, távolabbi rokonoknak - szintén ki kell venniük részüket a gyermekek felügyeletéböl, annak érdekében, hogy az édesanyák el tudják látni egyéb teendőiket, többek között kellő időt és figyelmet tudjanak fordítani a többi gyermekükre is.

\section{2. ábra. Bronfenbrenner humánökológiai modellje.}

(forrás: Danis és Kalmár,2011,94.old)

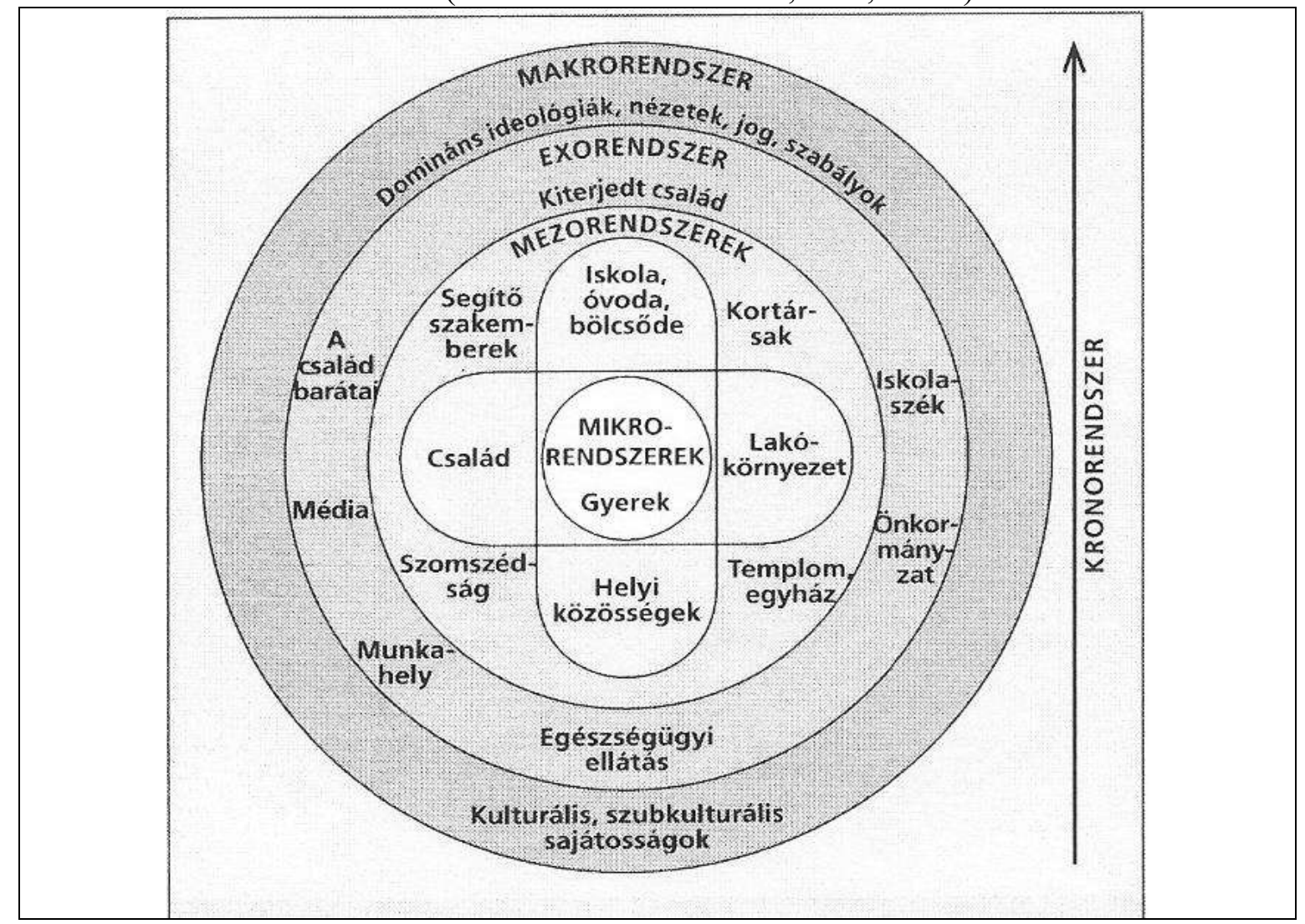

Ha nincs a közelben nagyszülő, testvér, a tágabb család, akkor a legalapvetőbb feladatok ellátása, például a bevásárlás, a gyógyszer kiváltása, a többi gyermek ellátása is problémát okozhat. A családok életritmusa általában a sérült gyermekhez alkalmazkodik, aki napi több órás folyamatos felügyeletet igényel. Kevesebb lehetőségük nyílik kimozdulni, szórakozni, ezért általában elszigetelődnek, elmagányosodnak, és ezzel csak még inkább magukra maradnak a problémáikkal. Ha mégis úgy döntenek, hogy a sérült gyermekkel együtt is aktív életet szeretnének élni, ahhoz hihetetlen energiabefektetésre van szükségük. A súlyoshalmozottan fogyatékos gyermekükkel sok esetben a lakásból való kijutás is problémás, nem beszélve az utazásról, ami tömegközlekedéssel szinte megoldhatatlan. De autóval sem egyszerü, hiszen a sérült gyermeket be kell tenni az autóba, vagy épp speciálisan átalakított jármüre van szükség az utaztatásához.

A családok, amelyeknek gyermekük születik, a környezetük különböző közösségeinek a részét képezik immár az új szerepükben is úgy, hogy a gyermekük és annak a gyermekkora 
központi kérdéssé válik a számukra. A különböző családi tevékenységek és események tervezése és megvalósítása során a gyermekük aktív részvétele fontos szemponttá válik. Azokat a családokat azonban, ahol súlyos halmozottan sérült gyermek nevelkedik, a gyermekkor különleges kihívások elé állítja. De nem csak a klasszikusan értelmezett „gyermekkor”, hanem a gyermekük mindennapjai, a család mindennapi életének a megszervezése is, amelyet egyedül, ritkábban a tágabb családdal, még ritkábban egy fizetett segítővel együtt próbálnak megoldani. Utóbbi, az ún. „személyi segítségnyújtás” célja éppen a gyermek részvételének és a családnak a támogatása. A szülők támogatásával a személyi segítők, akik gyakran nem a család tagjai, hanem kívülről érkeznek, fontos szerepet játszanak abban, hogy a súlyos-halmozottan fogyatékos gyermek is részt vehessen a családi tevékenységekben. (Wilder, 2008).

A súlyos-halmozottan fogyatékos gyermek, a Bronfenbrenner-i értelmezés (2. ábra) szerint, hasonlóan a tipikusan fejlődő gyermekhez, egy rendszernek tekinthetö, amely több személyes jellemzővel (pl. életkor, egészség, kognitív képesség és motoros képesség) írható le. Minden rendszer célja a stabilitás, tehát ha zavar alakul ki a rendszerben, akkor reakciók indulnak be az egyensúly és a müködés visszaállítása érdekében. Ilyen helyzetek jelentkezhetnek, ha a súlyos-halmozottan fogyatékos gyermek az állapotán túl valamilyen betegséggel is küzd (pl. epilepsziával, vagy ételallergiával). A gyermek „müködését” azonban nemcsak a gyermek belső, személyes jellemzői befolyásolják, hanem külső hatások is, ráadásul a gyermek ökológiájának több szintjén.

A súlyos-halmozottan fogyatékos gyermekeknek, személyeknek a különböző helyzetekben való részvételével kapcsolatban szakmai egyetértés van abban, hogy az aktív részvétel előfeltétele a személy jó közérzete és fejlődése, valamint a velük kapcsolatos célok. A gyermekek részvételének fontosságát az Egyesült Nemzetek Gyermekek jogairól szóló egyezmény (CRC) 23. cikke (1) bekezdése is megerősíti: " Az Egyezményben részes államok elismerik, hogy a szellemileg vagy testileg fogyatékos gyermeknek emberi méltóságát biztosító, önfenntartását előmozdító, a közösségi életben való tevékeny részvételét lehetővé tevő, teljes és tisztes életet kell élnie." (Egyesült Nemzetek Közgyülése, 1989)

\section{A súlyos-halmozottan fogyatékosok „részvételének” az értelmezése}

A részvétel fogalma jelen írásban Granlund és mtsai. (2012) által adott meghatározáson alapul, miszerint a részvételnek két dimenziója van: részben a fizikai ottlét, vagyis a jelenlét, másrészt a részvétel kifejeződése, azaz a bevonódás, az aktivitás, az elkötelezettség foka.

A Nemzetközi Fogyatékossági és Egészségügyi Osztályozás (ICF) és ennek a gyermekekre és a fiatalokra vonatkozó változata (ICF-CY) hangsúlyozza az egyén részvételének a fontosságát. Ezekben a besorolásokban a részvételt úgy definiálják, mint a személy „életmódbeli részvételét", amely magában foglalja a teljesítményt is (pl. azt, amit az egyén a jelenlegi környezetében tesz, cselekszik). (Egészségügyi Világszervezet, 2004).

Az ICF és az ICF-CY biopszicho-szociális modellje szerint az egyén részvételét, részvételre irányuló erőfeszítéseit a személy érdekei és képességei, egyéb személyes jellemzői, (például az életkor vagy a nem és a környezeti jellemzők, vagyis a facilitátorok) befolyásolják vagy akadályozzák (azaz korlátok). (Egészségügyi Világszervezet, 2004).

Egy tematikus szakirodalmi áttekintésben Bult és munkatársai (2011) megállapították, hogy a nagymozgás és a finommotorika képessége, a kognitív képességek, a kommunikációs készségek, az életkor és a nem olyan változók, amelyek a különböző diagnózisú és életkorú gyermekek és fiatalok szabadidős tevékenységekben való részvételt a leginkább magyarázzák. A változók közötti eltérés szintje azonban viszonylag alacsony volt, ami azt jelzi, hogy számos egyéb tényező is fontos a részvétel gyakoriságához. Palisano a munkatársaival (2011) 205 agyi bénult fiatal és szüleik esetén keresztül tanulmányozta, hogy a nagyobb intenzitású 
részvételt (a tevékenységek számát és a gyakoriságát) milyen tényezők befolyásolják. Azt találta, hogy a jobb fizikai képesség, a fiatalabb életkor, a női nem és a család aktív életmódja a részvételt intenzívebbé teszi.

A fogyatékossággal élő személyek jogairól szóló ENSZ egyezmény (The Convention on the Rights of Persons with Disabilities (CRPD). A Fogyatékos Személyek Jogairól szóló ENSZ Egyezményt és a fakultatív jegyzőkönyvét 2007. július 20-án ratifikálta Magyarország.) 19. cikke kimondja az önálló életvitelhez való jogot, és azt a jogot, ami az „otthoni, intézményi és egyéb közösségi támogató szolgálathoz, beleértve azt a személyes segítséget, mely a közösségben éléshez és a közösségbe történő beilleszkedéshez, valamint a közösségtől való elszigetelődés és kirekesztődés megelőzése céljából szükséges" (2007. évi XCII. törvény a Fogyatékossággal élő személyek jogairól szóló egyezmény és az ahhoz kapcsolódó Fakultatív Jegyzőkönyv kihirdetéséröl)

Nyilvánvaló, hogy a súlyos-halmozottan fogyatékos gyermekek nem rendelkeznek ugyanazokkal a személyi erőforrásokkal a napi családi életben, mint a kevésbé súlyos fogyatékos és a tipikusan fejlődő gyermekek. A családi tevékenységekben való részvétel megkönnyítése érdekében a gyermekek a mikrokörnyezetükben elsősorban a szülők és a külső személyi segítök támogatását igénylik.

Tudásunkból még hiányoznak a súlyos-halmozottan fogyatékos gyermekeknek a családi tevékenységekben való részvételére vonatkozó ismereteink, valamint hogy a gyermekek támogatásával vagy a családban a gyermekekkel való kapcsolattartás támogatásával hogyan lehetne elérni a jobb részvételt. Pedig az ilyen ismeretek összegyüjtése lehetővé tenné a gyermekek aktivitásának és jólétének, valamint a súlyos-halmozottan fogyatékos gyermekek családjainak mindennapi életének a javítását.

A súlyos-halmozottan fogyatékos gyermekek esetében (is) az adott gyermek sajátosságainak a felismerése, azonosítása szükséges ahhoz, hogy a gyermek aktív résztvevője lehessen az élete minden vonatkozásának és az életminősége javításának. A súlyoshalmozottan fogyatékos gyermekek egyéni támogatása érdekében tehát fontos a gyermek személyiségének az ismerete, ami csak hosszú idő alatt, a gyermekkel való interakció során szerzett tapasztalatokkal érhető el. Ennek alapján a szülők és a személyi segítők azok, akik jelentősen befolyásolhatják a gyermekek részvételét a különböző helyzetekben.

\section{A súlyos-halmozottan fogyatékosok „részvétele”, mint a család függvénye}

A család, mint társadalmi intézmény, a mindennapi tevékenységek gazdag választékát kínálja, ahol a gyermek számára természetes tanulási lehetőségek állnak rendelkezésre (Dunst és mtsai. 2001). Gyermekkorban a család az, ami a legfontosabb és központi szerepet tölt be egy gyermek ökológiájában. A gyermek tehát nem elszigetelt rendszer, hanem a családjának vagy egy adott mikrorendszernek a része, azaz az ezek közötti összefüggés egyik eleme (Schalock, Fredericks, Dalke és Alberto, 1994). A mikrorendszerben a részek (az egyének) összekapcsolódnak és kölcsönösen függenek egymástól (2. ábra) (Danis és Kalmár, 2011). Ennek megfelelően a család minden egyes részének helyét és szerepét figyelembe kell venni a rendszer egészének a megértéséhez.

A gyermek egyedi rendszeréhez hasonlóan a család is az önstabilizációra törekszik, ami során a szülők a családjuk, a személyes vágyaik és a körülményeik között egyensúlyt keresnek (2. ábra), ami magában foglalja a napi rutinok betartását is, amit a fenntarthatóság, a „stabilitás” érdekében alakítottak ki. A rutinok és a rituálék rendszeresen naponta, hetente, havonta, évszakonként ismétlődő tevékenységeknek tekinthetőek. Például a család heti szokása, hogy melyik nap mi történik, mikor ér apa haza korábban, mikor történik a nagybevásárlás, melyik nap mennek a nagyszülőkhöz ebédre, melyik nap van a gyerekeknek edzése, mikor számítógépezhetnek, stb. A rutinok és a rituálék stabil keretet biztosítanak a 
mindennapi élethez és a szokásokhoz. A rituálék ezen kívül megalapozzák és fenntartják annak a megértését is, hogy mit jelent egy csoport tagjának lenni, és magában foglalja a szimbólumokkal való kommunikációt is. Rítusa lehet például a családi ünnepeknek, a születésnapoknak, vagy a családi játékoknak, a közös tevékenységeknek.

A rutinok és rituálék, valamint az egyéb tevékenységek egy családon belül elsősorban a család ökológiájától függenek, pl. a család erőforrásaitól, a korlátaitól, a kultúrájától (Weisner, 2002). A proximális folyamatok minden esetben kapcsolatot és fejlesztési lehetőséget jelentenek a gyermek és a gyermek közvetlen környezetében lévő személyek, tárgyak és szimbólumok között. Ezek a folyamatok valójában kölcsönhatások, amelyek azonnali külső környezetben zajlanak, meglehetősen rendszeresen, hosszabb időn keresztül, és példaként szolgálhatnak a szülö-gyermek tevékenységek, a játék és az új készségek elsajátításában. A proximális folyamatok minősége kiemelkedő fontosságú a gyermekek jólétének és fejlödésének szempontjából (Bronfenbrenner és Evans, 2000). Bronfenbrenner és Ceci (1994) szerint a proximális folyamatok a fejlödés motorjainak mondhatók, míg egy személy és a környezet jellemzői biztosítják a szükséges erőt/energiát/motivációt/indítékot, és a kormányzat nagy részét. Az egyik ilyen kontextuális tényező a súlyos-halmozottan fogyatékos gyermekek és családjaik számára a személyes segítség.

\section{A súlyos-halmozottan fogyatékosok „részvétele”, mint a külsö segitők függvénye}

A súlyos-halmozottan fogyatékos gyermekek állapota a családban feszültséget kelthet, mivel a családi rendszer egyensúlyát megbillenti, ami a rendszerelmélet szerint, támogatással, ezen belül is személyi támogatással (személyi segítő, személyi gondozó) visszaállítható. A személyi segítő lehet fizetett rokon (gyermekek esetében általában az egyik szülö) vagy egy külső, alkalmazott személy. Utóbbi esetben a fogyatékos gyermek szociális hálójának belső köréhez egy külső személy, a segítő is bekerül. Ez a segítő gyakran a család tagjává is válik (Wilder, 2008).

Skär és Tamm (2001) a fogyatékos gyermekek és a segítők kapcsolatát vizsgálták olyan 819 évesek körében, akik az állapotuk mellett jó kommunikációs képességekkel rendelkeztek. Vizsgálatuk során a személyi segítőnek azokat a jellemzőit keresték, amelyek a gyermekek számára fontosak voltak. E szerint az a személyi segítő az ideális, akiben megbízhatnak, akikkel bizalmasak lehetnek és biztonságban érzik magukat vele, érti és ismeri a sajátos szükségleteiket, aki kedves és vidám, és barátként tekinthetnek rá. A visszajelzések szerint az a segítő, aki a felsorolt tulajdonságokkal rendelkezik, nagyobb eséllyel tudja segíteni a függetlenség és az autonómia kialakulását és fejlődését. Az interjúk során a gyerekek és a fiatalok hangsúlyozták annak fontosságát is, hogy saját maguknak is lehessen beleszólásuk az ideális segítőjük kiválasztásában.

A fiatalok által mondottak összecsengenek egy olyan vizsgálat tapasztalataival is, ami felnőttek körében történt (Roos, 2009). A felnőttek szerint a külső személyi segítőnek diszkrétnek kell lennie, alkalmazkodnia kell (azaz a segített személy kívánságainak megfelelően járjon el), legyen megbízható, informatív, figyelmes és körültekintő, tiszteletteljes, barátságos, vidám és jó problémamegoldó.

A személyi segítségnyújtásnak kettős célja van, a gyermekek részvételének és a szülöknek a támogatása. A gyermek otthonában nyújtott személyi segítség azonban a család magánéletére is hatással lehet. A gyermek otthonában dolgozó „idegen személy" feszültséget, bizonytalanságot okozhat a családi magánélet határainak a meghúzásában és átlépésében (Ahlström és Wadensten, 2011; Clevnert és Johansson, 2007). Másrészt viszont, ha a szülő a szülői szerepe mellett a gyermeke személyi segítője is, akkor a különböző feladatok, a gondozói szereppel kapcsolatos elvárások miatt a szülő szerepkonfliktusba kerülhet önmagával és a család többi tagjával is. Ez a belső konfliktus az ára annak, hogy javulhat a 
család anyagi helyzete, hogy a szülö ilyen módon hozzájárul a családi költségvetéshez (Clevnert és Johansson, 2007).

\section{A súlyos-halmozottan fogyatékosok „részvétele” a mindennapokban}

Ahhoz, hogy megértsük a személyes segítségnyújtás fontosságát a súlyos-halmozottan fogyatékos gyermekek tevékenységben való részvételében, a „részvétel” fogalmát tovább kell vizsgálni.

A súlyos-halmozottan fogyatékos személyeket érintő vizsgálatok és kutatások többszempontból is komoly nehézségeket jelentenek, etikai és módszertani átgondolásokat igényelnek. Ideális esetben a súlyos-halmozottan fogyatékos gyerekeknek is lehetöséget kell adni a saját részvételi tapasztalataikról való beszámolókhoz (Simeonsson és mtsai., 2003). A kommunikáció súlyos nehézsége miatt azonban a kutatók ritkán kérdezik meg magukat az érintetteket arról, hogy szeretnének-e részt venni a kutatásban, vagy a vizsgálatok során a családi tevékenységekben való részvételükről, arról, a részvétel elősegítéséről, a személyi segítöikről. A súlyos-halmozottan fogyatékos személyeknek a kommunikációja, elsősorban a verbális kommunikációja nehezített, sok esetben teljesen hiányzik. A hiányzó kommunikáció következményeként a környezettel való kontaktus felvétel nehezített, legyen az szükebb vagy tágabb környezet, ennek a következménye pedig az izoláció.

Maguknak a súlyos-halmozottan fogyatékos gyermekeknek egy őket is érintő kutatásban elsődleges fontosságúnak kell (ene) lenniük, annak ellenére, hogy a súlyos-halmozottan fogyatékos személlyel a közös munka rendkívül nehéz. A kutatók a szülökre és a megkérdezett személyi segítőkre támaszkodtak, akik jól ismerik a gyerekeket, és képesek értelmezni a gyermekek jelzéseit (Coster és mtsai., 2012; Verdugo , Schalock, Keith és Stancliffe, 2005). A kutatók a szülőkre és a segítőkre támaszkodnak, és azt kérik, hogy „képzeljék” magukat a gyermek helyzetébe vagy gondolkodjanak az érintett személy fejével, hogy mit gondol, hogyan érez dolgokról (Sommer, Samuelsson és Hundeide, 2010).

A nehézség abból fakad, hogy mindenki a képességeinek és a „müködési” korlátoknak egy egyedülálló mintázata, így a kommunikációs repertoárja is egyedi (Nakken és Vlaskamp, 2007). Másrészt, a megfigyelések zavarhatják a családi életet és a magánéletet. Mindazonáltal fontos hangsúlyozni, hogy a tapasztalataink és a szakmai tudás gyarapítása a témában remélhetőleg pozitív hatással lesz a gyermekekre és családjaikra (Maes, Vos és Penne, 2010).

A gyermekek részvételét számos külső (környezeti) és belső (személyes) tényező befolyásolja, amely akadályként vagy facilitátorként hat. A gyermekek gyenge mozgásos képességeit (érthetően) negatívan akadályozó tényezőként éli meg a legtöbb család. Közös tevékenységként éppen emiatt gyakrabban választhatják a játszótéri játékot vagy a sétálást, ahol a gyermekek a hintában, a homokozóban vagy a babakocsiban/kerekesszékben jól érzik magukat. Ezzel szemben még a nagyobbak is, föleg, ha a finommotorikus vagy a kognitív képességek is érintettek, ritkábban internetezhetnek vagy olvashatnak.

Kevés az olyan kutatás, amelyik a súlyos-halmozottan fogyatékos gyermekeknek a különböző családi tevékenységekben való aktivitását vizsgálták, de ezek egyetértenek abban, hogy pl. az agyi sérült gyermekek (Imms és mtsai 2008), a súlyos mozgássérült és/vagy komplex kommunikációs szükségletü gyermekek közül (Raghavendra és mtsai. 2011) a legsúlyosabb fogyatékossággal élő gyermekek kevésbé intenzív és kevesebb fajta tevékenységekben vettek részt, mint a kevésbé súlyos állapotú gyermekek, valamint inkább otthoni, nem pedig közösségbeli tevékenységekben vesznek részt. Más tanulmányok szerint azonban az érintett gyermekek ugyanolyan mértékben élvezik a tevékenységeket, mint a tipikusan fejlődő gyermekek (Engel-Yeger, Jarus, Anaby és Law, 2009; King, Shields, Imms, Black és Ardern, 2013; Ullenhag, Krumlinde-Sundholm, Granlund és Almqvist, 2014). 
Ha a két gondolatot (az említett vizsgálati eredményeket) összekapcsoljuk, azt mondhatjuk, hogy vannak tevékenységek, amelyekben a súlyos-halmozottan fogyatékos gyermekek ritkábban vettek részt kortársaikhoz képest (pl. a szabadtéri tevékenységekben), de ha mégis ilyen helyzetbe kerültek, akkor a bevonódásuk, lelkesedésük, érdeklődésük alig különbözött a tipikusan fejlődő gyermekekhez képest. Néhány mindennapos tevékenységben (pl. a „,reggeli rutinok" és az „esti rutinok") azonban a súlyos-halmozottan fogyatékos gyermekek a jóval kisebb aktivitást mutatták, talán mert a gyermekek ezeket a tevékenységeket érdektelennek találják, vagy a felnőttek rutinszerüen végzik a tevékenységet, ami közben kevésbé észlelik és reagálnak a súlyos-halmozottan fogyatékos gyermekeknek a gyengébb kifejezéseire, jelzéseire (Iacono, Carter és Hook, 1998).

Axelsson $(2014,2015)$ a vizsgálatában súlyos-halmozottan fogyatékos és tipikusan fejlődő gyerekek tevékenységeit és azok jellegét és gyakoriságát hasonlította össze. A munkájában hét csoportba sorolt (beltéri tevékenységek, étkezések, rutinok, szabadtéri tevékenységek, szervezett tevékenységek, kirándulások, nyaralás) 53 tevékenységformát (néhány az 53 tevékenységformából: Filmnézés; Kézműves foglalkozás; Háziállatokkal való játék; Olvasás; Főzés; Mosogatás; Az asztal terítése, leszedése; Teázás, kávézás együtt; Együtt vacsorázni; Takarítás; Az ,iskolatáska” bepakolása másnapra; Kertészkedés; Játék más gyermekekkel; Játék felnőttekkel; Csavargás, séta; Játék a homokozóban; Játszóterezés; Könyvtárba menni; Színházba, moziba, koncertre menni; Nyaralás; TV-nézés; Internetezés; Hangszeren zenélés; Gyógytorna gyakorlása otthon; Pihenés; Labdajátékok; Fejlesztő foglalkozásra menni; A felnőtt gyermekes barátjának a meglátogatása; stb.), amelyekben tipikusan fejlődő és súlyoshalmozottan fogyatékos gyermekek csoportját, illetve a velük szoros kapcsolatban álló felnőtteket figyelt meg. Eredményei alapján nem volt olyan tevékenység, amit a különböző szempontok szerinti súlyos-halmozottan fogyatékos gyerekek gyakrabban végeztek volna a kortársaiknál. A súlyos-halmozottan fogyatékos gyerekek csoportján belül (a tevékenységeket összehasonlítva) négy esetben volt magasabb az arányszám: „filmnézés", „zenehallgatás", „pihenés" és „sétálás". A súlyos-halmozottan fogyatékos gyermekek aránya (csak) ezekben a tevékenységekben volt ugyanolyan, de nem magasabb, mint a tipikusan fejlődő gyermekek esetében. Az eredményei azt mutatják, hogy a súlyos-halmozottan fogyatékos gyermekek ritkábban vesznek részt az otthonukon kívüli tevékenységekben, miközben gyakoribb volt a nem fizikailag aktív tevékenységük. A gyermekek jelenlétének gyakoriságával és arányával kapcsolatos legnagyobb különbségeket a szabadtéri tevékenységek, a szervezett tevékenységek és kirándulások, azaz az otthonukon kívüli tevékenységek területén tapasztalta. Feltünő, hogy négy rutin tevékenységben azonban (a ,reggeli rutinokban", az „esti rutinokban", ,az iskolatáska előkészítésében" és a ,játékok elpakolásában") a súlyoshalmozottan fogyatékos gyerekek jellemzően nem vagy alig vettek részt, miközben a tevékenység hetente vagy naponta, és saját otthonukban, a családjuk körében történt.

\section{A mindennapokban való „, részvétel”, mint a szülők függvénye}

A családi tevékenységeket, annak gyakoriságát és sokféleségét a szülők által a gyermek számára biztosított tevékenység-lehetőségeknek tekinthetjük. A mindennapokból ismert, hogy a súlyos-halmozottan fogyatékos gyermekek családjai kevesebb féle tevékenységet találnak ki és szerveznek meg, s azokat is ritkábban, mint egy átlagos családban. Ez akkor is igaz, ha a „tevékenység” kifejezésbe az otthoni közös filmnézést vagy főzőcskézést és a takarítást is beleértjük.

Különböző, a szabadidő felhasználásáról szóló vizsgálatokból tudjuk, hogy a gyermekes családok közös programjai, tartalmuk és gyakoriságuk függnek a család jövedelmétől és a szülők iskolai végzettségétől. Végig gondolva a súlyos-halmozottan fogyatékos gyermekek családjaival kapcsolatos ismereteinket, az feltételezhetö, hogy a család anyagi helyzete 
erősebben hat a szabadidő eltöltésére, mint a tipikusan fejlödő gyerekes családokban. A szülök iskolai végzettsége viszont kevésbé lehet meghatározó a súlyos-halmozottan fogyatékos gyermekes családokban, hiszen a közös filmnézés, a zenehallgatás, a játék, a séta vagy az olvasás kevésbé függ az iskolázottságtól.

A családi tevékenységek gyakorisága és változatossága, valamint a gyermekek jelenléte a tevékenységekben a felnőttek, a szüleik és a személyi segítőik ötletességétől, praktikusságától függenek, és attól, hogy mennyire fontos szempont számukra az „örömszerzés”, az élmény biztosítása. Néhány kivétel található olyan tevékenységekben, amelyek úgy tekinthetők, hogy kevésbé igényelnek fizikai tevékenységet a gyermekektől, például ,zenét hallgatni" és „sétálni" (a gyermek valószínüleg kerekesszékkel). Ez kapcsolódhat Dunst és munkatársai tapasztalataihoz (2001), akik úgy találták, hogy azok a súlyos-halmozottan fogyatékos gyermekek, akik változatosabb tevékenységekben vettek részt, nagyobb és többirányú aktivitást, érdeklődést mutatnak, mint a kevésbé változatos tevékenységben résztvevő gyermekek. Emellett a szerzők a gyermek fejlődése szempontjából fontosnak tartják a tevékenység ösztönzésének, a proximális folyamatokban való részvétel gyakoriságának, valamint az e tevékenységekben eltöltött idő hosszának a hangsúlyozását is.

A mindennapokban azonban, nyilvánvaló, hogy a szülők számára a súlyos-halmozottan fogyatékos gyermekek igényeinek a kielégítése időigényes, és oka lehet annak, hogy a családok kevesebb lehetőséget teremtenek a gyermeküknek (Tadema és Vlaskamp, 2010). De miközben ezt megfogalmazzuk, nem szabad elfeledkeznünk arról, hogy a szülök a család egészének, a teljes család müködésének akarják a legjobbat, vagyis azt, ami a legjobb egyensúlyt eredményezi a családi rendszerben.

A súlyos-halmozottan fogyatékos gyermekeknek támogató környezetre van szükségük, és fontos, hogy a tevékenységüket elősegítsék, támogassák (pl. a környezet átalakításával), hogy a gyermekek számára is kivitelezhető legyen a tevékenység. Érdemes külön is kihangsúlyozni a gyermekek számára elfogadható tevékenységek fontosságát, s hogy a gyermekek érdekeit, bevonódását, részvételét, kompetenciáját és teljesítményét a környezete is ösztönözheti. (Dunst és mtsai. 2001). Részben hasonló mintázatot írt le Law (és mtsai, 2006) a vizsgálatában. A testi fogytakos gyermekeket vizsgáló tanulmányban azt találták, hogy a gyermekek részvétele kevésbé volt változatos az alacsonyabb jövedelmü családokban. Ez azt jelentheti, hogy a családi jövedelem vagy facilitátor, vagy akadály lehet a fogyatékos gyermeket nevelö családok tevékenységében.

\section{A mindennapokban való „, részvétel”, mint a külsö személyi segitők függvénye}

A külső személyi segítők viszonya a családokhoz akkor megfelelő minden érintett számára, ha a külső segítő felismeri, hogy a jelenléte kompromisszumot jelent a család számára, és hogy szerepének folyamatosan változnia, sőt fejlődnie kell. Kommunikációjuknak nyitottnak, tiszteletteljesnek és egyezségre törekvőnek kell lennie. Szükséges, hogy a külső személyi segítők a feladatuk ellátása során, a szülőkkel való kapcsolatukkal segítsék a családok mindennapi életét és a nehézségek csökkentését. A segítők lényegesen gyakrabban segítik a gyermekeket a számítógépes játékokban, a más gyerekekkel (akár testvérrel is) való találkozásban és játékban, vagy éppen abban, hogy könyvtárba menjenek. A megkérdezett szülők és személyi segítők úgy írták le a külső személyi segítők feladatát, mint a gyermek alapvető funkcióinak a segítése, a mindennapi élet, a kapcsolattartás és a fejlődés támogatása. Mindez egybe esik az ICF és az ICF-CY által felsorolt komponensekkel: test (funkciók és struktúra), tevékenység és részvétel (Egészségügyi Világszervezet, 2004). Nyilvánvaló, hogy a külső személyi segítők fontos környezeti tényezőt jelentenek, és a gyermekekkel kapcsolatos megerősítő szerepet játszanak. A személyes segítségnyújtást tehát, aminek célja 
az egyenlő életkörülmények és a teljes társadalmi részvétel előmozdítása, a gyermekek részvételének megkönnyítőjeként értelmezhetjük.

A külső személyi segítőknek nemcsak a súlyos-halmozottan fogyatékos gyermekkel, hanem a gyermek családjával kapcsolatos felelősségük is van, ami miatt „harmadik” féllé válnak és lehet, hogy nem mindig érzik magukat kényelmesen a családban harmadik személyként. Minél hosszabb ideig van ugyanaz a segítő a gyermek mellett, annál inkább összehangolódik a gyermekkel és a családdal.

A külső személyi segítők kívánt jellemzőit Roos (2009) kutatta, miszerint a személyi segítő diszkrét, engedelmes/irányítható (azaz a segítségnyújtó vágya szerint cselekszik), megbízható, informatív, figyelmeztető, tiszteletteljes, figyelmes, barátságos, elégedett és gyakorlatias.

\section{Stratégiák, amelyek elösegithetik a részvételt}

Bedell (és mtsai., 2005) által megkérdezett agyi sérült gyermekek szülei stratégiaként hangsúlyozták a tevékenység, a fizikai és társadalmi környezet megszervezését vagy módosítását. Mindezt azért, hogy a gyermekek társadalmi részvételét elősegítsék. Hasonlóképpen a kutatás eredményei arra mutatnak rá, hogy a tevékenységeknek a gyermek számára szórakoztatónak, érdekesek, vonzónak kell lennie. Ez összhangban van Heah (és mtsai., 2007) tapasztalataival, miszerint a megkérdezett szülők és a külső személyi segítők azt is hangsúlyozták, hogy a gyermek segítése jelentős ismereteket igényel. Mivel a szülök a gyermeküket legjobban ismerik, ezek a tudás fö szolgáltatói a külső személyi segítők számára, és a külső személyi segítők felelőssége, hogy megismerjék a gyermeket.

Horn és Kang (2012) felhívta a figyelmet a gyermekkel kapcsolatos ismeretek jelentőségére, elsősorban a kommunikációjukkal kapcsolatban, és egy hatékony egyéni oktatási program kidolgozásában. Az emberek/környezet segítségre szorulhatnak, hogy megértsék a súlyoshalmozottan fogyatékos gyerekek kommunikációs viselkedését. Whaley és Bennett (1991) a korai gyermekkorban való részvétel előmozdításáról szóló tanulmányukban a speciális szükségletü gyermekeknél azt is megállapította, hogy a választási lehetőségek biztosítása befolyásolta az elkötelezettséget. Ennek megfelelően elengedhetetlen a családon belüli tevékenységekben való jobb részvételre irányuló stratégiák előmozdítása, pl. (Axelsson 2014, 2015):

- A tevékenységek elérhetővé és a gyermek számára elfogadhatóvá tétele, amihez fizikailag adaptálni szükséges a tevékenységet.

- Fontosak azok a közeli környezetben élő személyek, akik a gyermeket jól ismerik, akik pozitív példát, modellt mutatnak, amivel bátorítják a gyermeket. Fontos, hogy a gyermek érezze az „oadatartozást”, hiszen a gyermek érzi a „helyét” egy adott közösségben, a közösség gondolkodásában, és aszerint akar majd bevonódni, részesévé válni.

- Fontos, hogy a gyerek tudja, értse, hogy mi történik vele és körülötte, segítve őt abban, hogy felkészüljenek a várható eseményekre, tevékenységre.

- Fontos, hogy a gyermeknek lehetősége legyen a helyzet befolyásolására, kérdéseket feltenni, elmondani a véleményét, akaratát, hogy részese legyen a számára fontos a döntéshozatalnak.

- Fontos annak az éreztetése, hogy a gyermekre (is) szükség van a sikerhez az adott feladatban, tevékenységben.

- A gyermek részvételét, aktivitását (bevonódását) befolyásolja az, hogy milyen tevékenységet választ a környezete a számára (is). A súlyos-halmozottan fogyatékos személyek esetében nagy vagy jelentős segítségre van szüksége a tevékenységek elvégzéséhez. A szükséges segítség mértékét gyakran úgy csökkenti a (felnőtt) 
környezet, hogy olyan tevékenységet választ, ami kevesebb fizikai aktivitást igényel a sérülttől, mint például ,filmnézés" és ,zenehallgatás”.

\section{....és telnek a ,,mindennapok}

Egy család életében idővel a családi tevékenységek csökkennek, ami igaz a súlyoshalmozottan fogyatékos gyermeket nevelő családokra is. Esetükben annál is inkább igaz lehet ez az állítás, mert a szülők lelkesedése alább hagyhat a súlyos-halmozottan fogyatékos gyermekük gyenge vagy csak nehezen észrevehetető érdeklödése miatt. Ezen kívül várhatóan a súlyos-halmozottan fogyatékos gyermekek idővel csak bizonyos fajta és bizonyos aktivitást igénylő tevékenységeket fognak végezni vagy lehet velük együtt végezni. Bizonyos események pedig meg sem jelennek az életükben, még később sem, mintha egy bizonyos tevékenységtípusra „szakosodtak" volna. Ez valószínüleg fontos hatással van a gyermek mindennapi müködésére és hosszabb távú fejlődésére, hiszen ha egy gyermek megismerkedik és részt vesz bizonyos tevékenységekben, akkor egyre ügyesebb is lesz benne, azaz fejlödik.

De nem szabad azt sem elfelejteni, hogy a súlyos-halmozottan fogyatékos gyermekek esetében azzal kell számolnunk, hogy a proximális folyamatok lassúak, sok időt vesznek igénybe, időnként úgy tünhet, hogy akár stagnál is. Ezért azoknak a stratégiáknak a megtalálása és alkalmazása, ami a súlyos-halmozottan fogyatékos gyermekeknek a családi tevékenységekben való jobb és gyakoribb részvételét erősíti, rendkívül fontos. Ez annál is fontosabb, mert a mindennapokban azzal találkozhatunk, hogy a súlyos-halmozottan fogyatékos gyermekek idővel egyre inkább izolálódnak, még saját családjukban is.

A súlyos-halmozottan fogyatékos gyermekek társadalmi hálózatában a tagok száma stabil, sőt akár idővel csökkenhet is, személyek kikerülhetnek a hálóból (pl. a nagyszülők, akik fontos ismeretekkel rendelkeznek a gyermekről; egy-egy közeli barát, mert elköltöznek; ritkán találkozik a testvérével, mert máshol tanul vagy saját családot alapít). Ezeket a kritikus kérdéseket figyelembe kell venni a súlyos-halmozottan fogyatékos gyermekek családi és a családon kívüli tevékenységében való részvételének megkönnyítése érdekében.

\section{Összegzés}

A súlyos-halmozottan fogyatékos gyermekeknek a családi tevékenységekben való részvétele legalább két dimenzióval, ,jelenléttel” és az „elkötelezettséggel” írható le. Ezeket a dimenziókat a különböző tényezők és a proximális (legközelebbi) folyamatok magját alkotó tényezők befolyásolják, amely tényezők teljes ereje befolyásolja a gyermek müködését.

A súlyos-halmozottan fogyatékos gyermek befolyásolja a család működését, és a család müködése hatással van a gyermekre, ami azzal jár, hogy ezek a családok másképpen működnek a tipikusan fejlődő gyermekes családoktól. Mindennapi szükségleteik kielégítése érdekében a súlyos-halmozottan fogyatékos gyermeket nevelö családokban - más családokkal összehasonlítva - eltolódnak a prioritások, akár magának a súlyos-halmozottan fogyatékos gyermekek személyére vonatkozóan is a családi tevékenységekben és idejük elosztásában. Bizonyos tevékenységek gyakrabban/ritkábban fordulnak elö az érintett családokban a tipikusan fejlődő gyermekekéhez képest.

A befolyásoló tényezők részben különböznek a jelenlétre és a bevonódásra vonatkozóan. Azokban a tevékenységekben, amelyekben a gyermekek jelen vannak, az aktivitásukat befolyásolják a gyermekek jellemzői, például a motoros (mozgásos) képességük, a kognitív képességük, a tevékenység típusa, amelyben részt vesznek, valamint a gyermekek környezetében élő embereknek a gyermekekre való reagálása és a rájuk gyakorolt hatása. 
A vizsgálatok azt mutatják, hogy a gyermek jelenlétét és elkötelezettségét a családi, társadalmi és gazdasági tényezők kisebb mértékben befolyásolják, mint a tipikusan fejlödő gyermekes családokban.

A korlátozó tényezők azt eredményezik, hogy a súlyos-halmozottan fogyatékos gyermekek a tipikusan fejlődő gyermekekhez képest kevesebb és kevésbé változatos tevékenységet folytatnak ahhoz, hogy a családi tevékenységekben a közeli proximális folyamatokban aktívan részt vegyenek. Ennek megfelelően a családi tevékenységekben való jobb részvételre vonatkozó stratégiák kidolgozása és alkalmazása fontosnak bizonyul. A családoknak viszont esetenként szükségük van egy olyan emberre, aki külső erőforrásként segít(het) a családi rendszer egyensúlyának megszerzésében vagy visszaszerzésében. A külső személyi segítségnyújtás magában foglalja azokat a szerepeket és az ezekkel járó feladatokat, amelyek fontosak a súlyos-halmozottan fogyatékos gyermekek családjában.

Továbbra is szükség van a gyermekek, a család és a külső személyi segítő közötti időbeli kölcsönhatásra vonatkozó kérdések széles körü és folyamatos vizsgálatára. Ezen kívül figyelembe kell venni azokat a kérdéseket is, amelyek a gyermekekből és a családjukból fakadnak, vagy éppen feléjük irányulnak. Az ilyen tudatosság és tudás segítene a beavatkozások (pl. a tanácsadás) és a javaslatok végrehajtásában a súlyos-halmozottan fogyatékos gyermekek családjai számára, amelyeknek legfontosabb célja, hogy javítsák a gyermekek részvételét a mindennapi élet folyamataiban.

\section{Irodalom}

1991. évi LXIV. törvény a Gyermek jogairól szóló, New Yorkban, 1989. november 20-án kelt

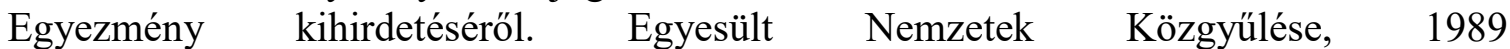
https://net.jogtar.hu/jogszabaly?docid=99100064.TV letöltve: 2015. 05. 20.

32/2012. (X.8.) EMMI rendelet a Sajátos nevelési igényü gyermekek óvodai nevelésének iránylevei és a Sajátos nevelési igényü tanulók iskolai oktatásának irányelve kiadásáról. 3.melléklet.

https://net.jogtar.hu/jogszabaly?docid=A1200032.EMM\&txtreferer=A1100190.TV letöltve: 2013. 04. 03.

2007. évi XCII. törvény a Fogyatékossággal élő személyek jogairól szóló egyezmény és az ahhoz kapcsolódó Fakultatív Jegyzőkönyv kihirdetéséről. https://net.jogtar.hu/jogszabaly?docid=a0700092.tv letöltve: 2015. 05. 20.

Az alapvető jogok biztosának Jelentése az AJB 1672/2017.számú ügyben. (Kapcsolódó ügyek: 1628/2017., 1671/2017. Előzmények: 1989/2016.) Alapvető Jogok Biztosának Hivatala

https://www.ajbh.hu/documents/10180/2602747/Jelent\%C3\%A9s+a+fogyat\%C3\%A9kos+gy ermekek+oktat $\% \mathrm{C} 3 \% \mathrm{~A} 1 \mathrm{~s} \% \mathrm{C} 3 \% \mathrm{~A} 1 \mathrm{nak}+\mathrm{k} \% \mathrm{C} 3 \% \mathrm{~A} 9 \mathrm{rd} \% \mathrm{C} 3 \% \mathrm{~A} 9 \mathrm{~s} \% \mathrm{C} 3 \% \mathrm{~A} 9 \mathrm{ben}+1672 \_20$ 17/db0718bc-9a94-80a3-5c48-ee2e490f8257?version=1.0

Ahlström, G., és Wadensten, B. (2011): Family members' experiences of personal assistance given to a relative with disabilities. Health és Social Care in the Community, 19(6), 645652. doi: 10.1111/j.1365-2524.2011.01006.x

Axelsson, A. K. (2014): Children with profound intellectual and multiple disabilities and their participation in family activities. Doctoral Thesis. School of Health Sciences Dissertation Series No 49. School of Health Sciences, Jönköping University ISBN 978-91-85835-485

Axelsson A. K. (2015): The role of the external personal assistants for children with profound intellectual and multiple disabilities working in the children's home. JARID: Journal of 
applied research in intellectual disabilities, ISSN 1360-2322, E-ISSN 1468-3148, Vol. 28, no 3, p. 201-211. doi: 10.1111/jar.12122. Epub 2014 Sep 1.

Bedell, G.M., Cohn, E.S. és Dumas, H.M. (2005): Exploring parents' use of strategies to promote social participation of school-age children with acquired brain injuries. American Journal of Occupational Therapy, 59(3), 273-284.

Bronfenbrenner, U. és Ceci, S. J. (1994): Nature-nurture reconceptualized in developmental perspective - a bioecological model. Psychological Review, 101(4), 568-586. doi: 10.1037/0033-295x.101.4.568

Bronfenbrenner, U. és Evans, G. W. (2000): Developmental science in the 21st century: Emerging questions, theoretical models, research designs and empirical findings. Social Development, 9(1), 115-125. doi: 10.1111/1467-9507.00114

Bult, M.K., Verschuren, O., Jongmans, M.J., Lindeman, E. és Ketelaar, M. (2011): What influences participation in leisure activities of children and youth with physical disabilities? A systematic review. Research in Developmental Disabilities, 32(5), 1521 1529. doi: 10.1016/j.ridd.2011.01.045

Clevnert, U. és Johansson, L. (2007): Personal assistance in Sweden. Journal of Aging \& Social Policy, 19(3), 65-80. doi: 10.1300/J031v19n03_05

Coster, W., Law, M., Bedell, G., Khetani, M., Cousins, M. és Teplicky, R. (2012): Development of the participation and environment measure for children and youth: Conceptual basis. Disability and Rehabilitation, 34(3), 238-246. doi: 10.3109/09638288.2011.603017

Danis. I. és Kalmár, M. (2011): a fejlődés természete és modelljei. In: Danis, I., Farkas, M., Herczog, M. és Szilvási, L. (szerk.)(2011): A génektől a társadalomig: a koragyermekkori fejlődés színterei Biztos Kezdet Kötetek I. Budapest 2011 Nemzeti Család- és Szociálpolitikai Intézet (korábban Szociálpolitikai és Munkaügyi Intézet), 76-125.o.

Dunst, C. J., Bruder, M. B., Trivette, C. M., Hamby, D., Raab, M. és Mclean, M. (2001): Characteristics and consequences of everyday natural learning opportunities. Topics in Early Childhood Special Education, 21(2), 68-92. doi: 10.1177/027112140102100202

Egészségügyi Világszervezet (2004): A funkcióképesség, fogyatékosság és egészség nemzetközi osztályzása, Budapest, EVSz-EszCsM-OEP

Engel-Yeger, B., Jarus, T., Anaby, D. és Law, M. (2009) Differences in patterns of participation between youths with cerebral palsy and typically developing peers. American Journal of Occupational Therapy, 63(1), 96-104.

Fröhlich, A. (1996): Életterek - életálmok. In: Márkus E. (szerk.): Halmozottan sérült, súlyosan mozgáskorlátozott gyermekek nevelése, fejlesztése. BGGYTF, Budapest, 15-25.

Granlund, M., Arvidsson, P., Niia, A., Björck-Åkesson, E., Simeonsson, R., Maxwell, G., et al. (2012): Differentiating activity and participation of children and youth with disability in Sweden: A third qualifier in the international classification of functioning, disability, and health for children and youth? American Journal of Physical Medicine and Rehabilitation, $91 \quad(13$ Suppl 1) pp. S84-S96 91(13), 84-96. doi: 10.1097/PHM.0b013e31823d5376

Hanna, S. (2006): Patterns of participation in recreational and leisure activities among children with complex physical disabilities. Developmental Medicine and Child Neurology, 48(5), 337-342. doi: 10.1017/S0012162206000740

Heah, T., Case, T., Mcguire, B. és Law, M. (2007): Successful participation: The lived experience among children with disabilities. Canadian Journal of Occupational Therapy, 74(1), 38-47. doi: dx.doi.org/10.2182/cjot.06.10

Horn, E. és Kang, J. (2012): Supporting young children with multiple disabilities: What do we know and what do we still need to learn? Topics in Early Childhood Special Education, 31(4), 241-248. doi: 10.1177/0271121411426487 
Iacono, T., Carter, M. és Hook, J. (1998): Identification of intentional communication in students with severe and multiple disabilities. Augmentative and Alternative Communication, 14(2), 102-114.

Imms, C., Reilly, S., Carlin, J. és Dodd, K. (2008): Diversity of participation in children with cerebral palsy. Developmental medicine and child neurology, 50(5), 363-369. doi: 10.1111/j.1469-8749.2008.02051.x

King, M., Shields, N., Imms, C., Black, M. és Ardern, C. (2013): Participation of children with intellectual disability compared with typically developing children. Research in Developmental Disabilities, 34(5), 1854-1862. doi: 10.1016/j.ridd.2013.02.029

Law, M., King, G., King, S., Kertoy, M., Hurley, P., Rosenbaum, P., Maes, B., Vos, P. és Penne, A. (2010): Analysis of daytime activities for children with profound intellectual and multiple disabilities in specific settings. The British Journal of Development Disabilities, 56(111), 123-136. doi: 10.1179/096979510799102907

Márkus, E. (2003):A súlyos-halmozott fogyatékosság meghatározásának problémái nevelési és szociális szempontból. Gyógypedagógiai Szemle XXXI. évfolyam 3176 -182. )

Márkus, E. (2009): a súlyos-halmozott fogyatékossággal élõ emberek megsegítésének elméleti megalapozása. In: A súlyos és halmozott fogyatékossággal élõ emberek helyzete magyarországon. Tanulmánykötet - második rész. Fogyatékosságtudományi Tanulmányok VII. Disability Studies. Eötvös Loránd Tudományegyetem Bárczi Gusztáv Gyógypedagógiai Kar. 34-54.old.

Nakken, H. és Vlaskamp, C. (2002): Joining forces: Supporting individuals with profound multiple learning disabilities. Tizard Learning Disability Review, 7(3), 10-15. doi: $10.1108 / 13595474200200023$

Nakken, H. és Vlaskamp, C. (2007): A need for a taxonomy for profound intellectual and multiple disabilities. Journal of Policy and Practice in Intellectual Disabilities, 4(2), 8387. doi: 10.1111/j.1741-1130.2007.00104.x

Palisano, R. J., Orlin, M., Chiarello, L. A., Oeffinger, D., Polansky, M., Maggs, J. és Stevenson, R. (2011): Determinants of intensity of participation in leisure and recreational activities by youth with cerebral palsy. Archives of Physical Medicine and Rehabilitation, 92(9), 1468-1476. doi: 10.1016/j.apmr.2011.04.007

Raghavendra, P., Virgo, R., Olsson, C., Connell, T. és Lane, A. E. (2011): Activity participation of children with complex communication needs, physical disabilities and typically-developing peers. Developmental Neurorehabilitation, 14(3), 145-155. doi: $10.3109 / 17518423.2011 .568994$

Roos, J. M. (2009). Quality of personal assistance shaped by governments, markets and cooperations. (Doctoral Thesis), University of Gothenburg, Göteborg. letöltve: 2018.01.14. https://gupea.ub.gu.se/bitstream/2077/19351/1/gupea_2077_19351_1.pdf

Schalock, M. D., Fredericks, B., Dalke, B. A. és Alberto, P.A. (1994): The house that traces built - a conceptual-model of service delivery systems and implications for change. Journal of Special Education, 28(2), 203-223.

Simeonsson, R. J., Leonardi, M., Lollar, D., Bjorck-Akesson, E., Hollenweger, J. és Martinuzzi, A. (2003): Applying the international classification of functioning, disability and health (ICF) to measure childhood disability. Disability and Rehabilitation, 25(11-2), 602-610. doi: 10.1080/0963828031000137117

Skär, L. és Tamm, M. (2001): My assistant and I: Disabled children's and adolescents' roles and relationships to their assistants. Disability \& Society, 16(7), 917-931. doi: 10.1080/09687590120084010

Sommer, D., Samuelsson, I. P. és Hundeide, K. (2010): Child perspectives and children's perspectives in theory and practice, 2 (Vol. 2): Springer. 
Tadema, A. C. és Vlaskamp, C. (2010): The time and effort in taking care for children with profound intellectual and multiple disabilities: A study on care load and support. British Journal of Learning Disabilities, 38(1), 41-48. doi: 10.1111/j.1468-3156.2009.00561.x

Ullenhag, A., Krumlinde-Sundholm, L., Granlund, M. és Almqvist, L. (2014): Differences in patterns of participation in leisure activities in Swedish children with and without disabilities. Disability and Rehabilitation, 36(6), 464-471. doi: 10.3109/09638288.2013.798360

Verdugo, M. A., Schalock, R., Keith, K. és Stancliffe, R. (2005): Quality of life and its measurement: Important principles and guidelines. Journal of Intellectual Disability Research, 49(10), 707-717. doi: 10.1111/j.1365-2788.2005.00739.x

Weisner, T. S. (2002): Ecocultural understanding of children's developmental pathways. Human Development, 45, 275-281. doi: 10.1159/000064989

Whaley, K. T. és Bennett, T.C. (1991): Promoting engagement in early childhood special education. Teaching Exceptional Children, 23(4), 51-54.

Wilder, J. (2008): Proximal processes of children with profound multiple disabilities. (Doctoral thesis), Stockholm University, Sweden, Stockholm. letöltés: 2017.10.23. https://www.diva-portal.org/smash/get/diva2:199674/FULLTEXT01.pdf 